Nouvelle Revue Synergies Canada

\title{
A Chat with Émile Zola, The Globe, Toronto, 1892
}

\section{Geneviève De Viveiros}

Numéro 13, 2020

Objets de l'écrivain : images, usages, représentations depuis le XIXe siècle à nos jours

URI : https://id.erudit.org/iderudit/1078434ar

DOI : https://doi.org/10.21083/nrsc.vi13.5741

Aller au sommaire du numéro

Éditeur(s)

University of Guelph, School of Languages and Literatures

ISSN

2292-2261 (numérique)

Découvrir la revue

Citer ce document

De Viveiros, G. (2020). A Chat with Émile Zola, The Globe, Toronto, 1892.

Nouvelle Revue Synergies Canada, (13), 1-6.

https://doi.org/10.21083/nrsc.vi13.5741 d'utilisation que vous pouvez consulter en ligne. 


\title{
A Chat with Émile Zola, The Globe, Toronto, 1892
}

\author{
Geneviève De Viveiros \\ Université Western Ontario \\ Canada
}

D'après le journaliste Henry Leyret, Émile Zola est en 1893, « l'homme le plus interviewé de France » (Speirs et Signori xiii). Nous reproduisons ici un entretien de Zola publié dans le quotidien canadien The Globe (l'ancêtre du Globe and Mail) en date du 12 novembre 1892.

L'entretien est réalisé par Carl Sadakichi-Hartman (1867-1944), poète symboliste et critique d'art américain. D'origines japonaise et allemande, Sadakichi-Hartman avait émigré aux États-Unis en 1882. En plus d'articles dans les journaux, il écrit pour la scène et fait paraitre quelques recueils poétiques qui témoignent de son intérêt pour l'Orient et les formes de la poésie japonaise (par exemples, Drifting Flowers of the Sea and Other Poems (1904) ; Tanka and Haikai: Japanese Rhythms, (1916)). II séjourne à de nombreuses reprises à Paris, où il fréquente notamment Stéphane Mallarmé (Blake). Il a été l'un des premiers critiques d'art à écrire sur la photographie et, en plus d'avoir interprété différents rôles sur scène, il a figuré dans le film The Thief of Bagdad de Douglas Fairbanks en 1924.

Le genre de l'interview connait un essor important à la fin du $\mathrm{XIX}^{\mathrm{e}}$ siècle : perçue comme une communication en direct, prise sur le vif d'une personnalité, elle répond au besoin d'actualité et d'immédiateté qui définit le journal (Speirs et Signori xiii). Suivant la mode des reportages de la fin du siècle qui présentent les écrivains dans leur intimité, une grande attention est portée sur le décor où vit et écrit Zola : l'appartement de la rue de Bruxelles comme la demeure de Médan y sont décrits de manière détaillée ${ }^{1}$. La physionomie, les gestes, la voix, la personnalité et les habitudes de Zola sont scrutés ici à la loupe par le visiteur curieux. SadakichiHartman pose également des questions sur le processus créateur qui sous-tend l'écriture du romancier. L'illustration ${ }^{2}$ montre d'ailleurs Zola dans son cabinet de travail entouré de ses objets d'écriture.

L'interview a sans doute été traduite en anglais par Sadakichi-Hartman lui-même qui avait l'habitude de publier dans cette langue, dans la presse américaine, les entretiens et les souvenirs de ses rencontres avec les écrivains français ${ }^{3}$. L'article a également été reproduit dans The Saint Paul Pioneer Press, Nov. 13, 1892 et The Courier-Journal, Nov. 13, 1892.

Afin de faciliter la lecture, nous avons uniformisé l'orthographe et corrigé les fautes d'impression que l'on retrouve dans le texte original reproduit ci-dessous.

THE GLOBE, TORONTO, SATURDAY NOVEMBRE 12, 1892

\section{A CHAT WITH EMILE ZOLA Reminiscences of the author's early life Struggle with poverty How he breakfasted on one raw egg, And dined on three apples-a glimpse at the novelist's life at Medan.}

Paris, Nov. 1-It was only 9 am when I rang the bell at no $17^{4}$, rue de Bruxelles. My intention was merely to find out whether Zola was passing the Summer in his country house for I wished to renew an acquaintance which I had made accidentally several years ago.

To my astonishment, M. Zola himself opened the door and welcomed me.

"You are really lucky in finding me here. In Summer I am hardly to be seen six days in Paris. I only arrived last evening to attend to some business today. Four months of Parisian life every Winter suffices for me." 
"Do you always stay at Médan?"

He nodded: "What else can you expect of a bourgeois like me?"

"And always at work?"

"Naturally, if I pass two days without writing I will feel uncomfortable, if three days, I would fall sick. Every morning, I say to myself:- "Seize the pen". Writing is second nature to me, an absolute necessity, and he stroked his short beard, trimmed according to the latest fashion. He has grown old, since I last saw him. He's broad, high forehead is marked by three deep wrinkles and his hair and beard are slightly streaked with grey. His face is pale and his figure has lost much of its former stoutness. His shortsightedness has increased to such an extent that he cannot read or write without his eye-glasses.

"But it is time that I should be going. Perhaps you have no objection to accompany me". Zola locked the door behind and dusted his boots with a coloured silk handkerchief. I observed for the first time how small his hands and feet were in comparison to his large body.

It is very difficult to keep up a conversation with Zola. To strangers he does not show himself as he really is. Besides he is not a good conversationalist unless he is excited. Things that do not interest him he cuts short with a few sarcasms. He prefers to sit in slippers before an open fireplace among intimate friends, where it is not necessary to be brilliant and where he can say everything. Then he is really himself-modest, polite, interested in all you have to say and ready to express his private opinion with a sincerity that is very sympathetic.

Wishing to enliven him a little, and knowing his dislike for Americans, I made some remark in favor of American literature.

"Oh, the Americans annoy me. They steal my novels and put my names to books which I would be ashamed to have written. They read me, but don't understand me. I wonder if any of those Puritans suspect that [I live] a life just as respectable as they do."

"They probably believe that you lead a life like all Parisian men of fashion".

"Grand Dieu!" he exclaimed, laughingly. "Another wife besides my own! C'est impossible! That would be a loss of time for me. I always find friends, but never intimate female acquaintances ${ }^{5}$. Besides I am very difficult to please. The ladies call me an 'ours' (bear)".

He leads a laborious and sedentary life. Even as a young man he had never frequented cafes or drinking saloons. He has never belonged to a club, is never known to have touched cards, and, unlike most people, has no special taste for anything except literature; only in his youth he had a weakness for the clarion. His natural timidity, which is one of his leading characteristics, makes him avoid the salons and society in general, and if he spends a few weeks at the seashore in summer he never selects Trouville or Dieppe, but always the most secluded and unfrequented places.

As we were walking along the Boulevard St. Germain he took a large notebook out of his breast pocket and glanced over some clippings of criticisms on his last book, "L[a] $D$ [é]bâcle"." Despite his robust appearance, he is extremely nervous and sensitive, and some of the criticisms seemed to irritate him.

Perceiving that I was watching him with much interest, he exclaims, "Je suis toujours enragé! One says that Delacroix, thinking of what he had suffered during his long career, cried. 'I die enraged'. Well, Émile Zola, pointing to himself, lives "enraged", and he quickened his pace.

In spite of all that has been written on Zola of late, his childhood has remained comparatively unknown, and wishing to hear some details from the author himself, I managed to lead the conversation to that interesting topic. Walking along slowly he said:-“I was what they called a spoiled child. My father died when I was three, and my mother and grandmother allowed me to be as mischievous as I pleased, hardly ever scolding me. If they put a new suit on me and I came home an hour later covered with dirt they kissed me and found some excuse for my conduct. So it came to pass that at the age of eight I did 
not know my a, b, c. I was put to some unpretentious boarding school, and afterwards attended a college, both in Aix. Solary, the sculptor, and Marius Roux, the editor of The Petit Journal, were my best friends. 'Combien de galopinades, nous bambins avons faites!' In the beginning I was always à la queue of the class. I hated Greek and Latin and arithmetic, and only took a liking to science. In composition I was always first. The first thing I ever attempted to write was a large historical novel in six volumes, treating the crusades. The details were taken from Michaud."

Coming to the Boulevard St. Michel, he pointed out the direction of the new Sorbonne University and laughingly exclaimed:- "I shall never forget the verbal examination I passed over there. It was a complete failure. 'Let us have a little of history', began the professor. 'When did the death of Charles the Great occur?' The answer was 500 years astray, putting it into the reign of Francis I.

'Let us come to literature', said the professor, dryly, and desired the explanation of one of Lafontaine's fables. I have forgotten what I said, but it must have been exceedingly romantic, for it was in those days that I sat up the whole night reciting Musset and Victor Hugo. There was nothing of Balzac as yet.

'Let us come to German', resumed the professor, more dryly still.

"The examination was over. I did not know a word.

"You had a very hard time in Paris, I believe?"

"Always at the bottom of my purse," he said. "Very often I had not a sou left, and not knowing, either, where to get one. I rose generally at 4 in the morning, and began to study after a breakfast, consisting of one raw egg. But no matter, those were good times! After taking a walk along the quays I entered my garret and, joyfully partaking of a dinner of three apples, I sat down to work. I wrote and I was happy. In winter I could allow myself no fire; wood was too expensive-only on fête days I was able to afford it. But I had several pipes of tobacco and a candle for 3 sous. A 3-sous candle, only think of it! It meant a whole night of literature to me."

We had been walking in the Rue Montmartre, and arriving at a dirty, narrow by-street, the Rue StJoseph, Zola turned into it, telling me he had a surprise in store for me.

After passing a number of little shops, we stopped before a grey house with green shutters.

"Here, in the midst of teeming Paris, I was born, on the fifth floor of this house. But now, monsieur, you must excuse me. I have much business to attend to while I am in the city. Come see me at Médan".

Médan is a little village of 200 inhabitants at the most on the left bank of the Seine, near Poissy. It is as beautiful a spot as can be found in France, some of the peasants' huts being built along the highway on the side of a hillock covered here and there with groups of tall walnut trees, while the other cottages seem to have slipped to the very bottom of the slope where the trains of the Rouen railroad pass by. The village is surrounded by rich meadow land with grazing cows, long rows of willows and poplars, and orchards of peach and apple trees. Such is Médan. It seems as if one were 1000 miles away from Paris. The only fashionable house in the community is the "château" of M. Zola. When he bought it for 9000 francs it was but a dilapidated villa with a small, neglected park. For more than a year, however, it was in the hands of masons, carpenters and gardeners, and soon the value of the property had increased ten-fold and was rendered suitable to Zola's taste, love for comfort and great passion for work.

In this retreat the author of the Rougon Macquart lives eight months of the year. At 8 in the morning he leaves his large Louis XVI bed with its elaborate brass flutings. While he is dressing-in regular country style, vest and pantaloons of dark brown velvet-he catches a glimpse of the scenery outside in a large spotless mirror above the mantelpiece. It reveals the Seine looking like a silver bar in the light of the morn, while the poplars on the island opposite Zola's mansion, are scarcely seen in the mist. His toilet finished, he takes a short walk with his two dogs, Bertrand, a large Newfoundland, and the little mischievous terrier, Raton. Sometimes Mme Zola, taking his arm, accompanies him. If the water is not too cold, they enjoy looking on at Bertrand taking a bath. Half an hour later they return for the first breakfast. At 9 Zola begins to work. 
In his study everything is of enormous size. Considering its dimensions the room could serve for the studio of a historical painter. It is eighteen feet high, 36 feet long and 30 feet wide. A colossal mantelpiece, with the Latin inscription, "Nulla dies sine linea", and a fireplace where a whole sheep could be roasted, first attracts our attention. Equally unusual is a large divan with six cushions, which is almost as large as an ordinary room. The middle is occupied by a very large oaken table, with a huge inkstand representing a lion in bronze. A winding staircase leads to his library above and to the verandah below. A large bay window commands a splendid view upon his property.

From 9 to 1 Zola sits behind the large table, while his dogs play in a corner.

At 1 breakfast is served. The great novelist devotes almost the same care to his menu as to his books One is sure to have a good meal with him at any time. He is decidedly an epicure. From 2 to 3 he takes a nap. At 3 the mail arrives. Zola receives Le Figaro, l'Événement, Le Gaulois, Le Voltaire, and Le Gil Blas daily; for these he subscribes, while a large number of Parisian and provincial papers are sent to him free of charge. Letters are also numerous, but he seldom answers them, not even those of his friends.

At 4 he is done with reading and if the weather is fair and he has no proof sheets to correct, the family takes a trip in "Nana" a bark painted green, to the little island, on which Zola had a Swiss cottage built. They walk about, play an out-door game, take luncheon, read or rest on the green shady lawn, and do not return until dinner, which takes place at 7.30. After dinner, the table cloth is removed, and one chats over a cup of tea.

The same friends that visit him in the Rue Bruxelles visit him at Médan. Rosny, his pupil, Catulle Mendes, the romantic realist, Huysmans, Guy de Maupassant came regularly every Thursday night for years. Sometimes he plays a game of billiards with the curé of the village. And at 10 this thoroughly bourgeois family retires. All lights are put out except those in the author's room, for he is used to read in bed until 1. In this routine one day in Medan passes like another, the hours of recreation and study varying but little.-C. Sadakichi Hartmann. 


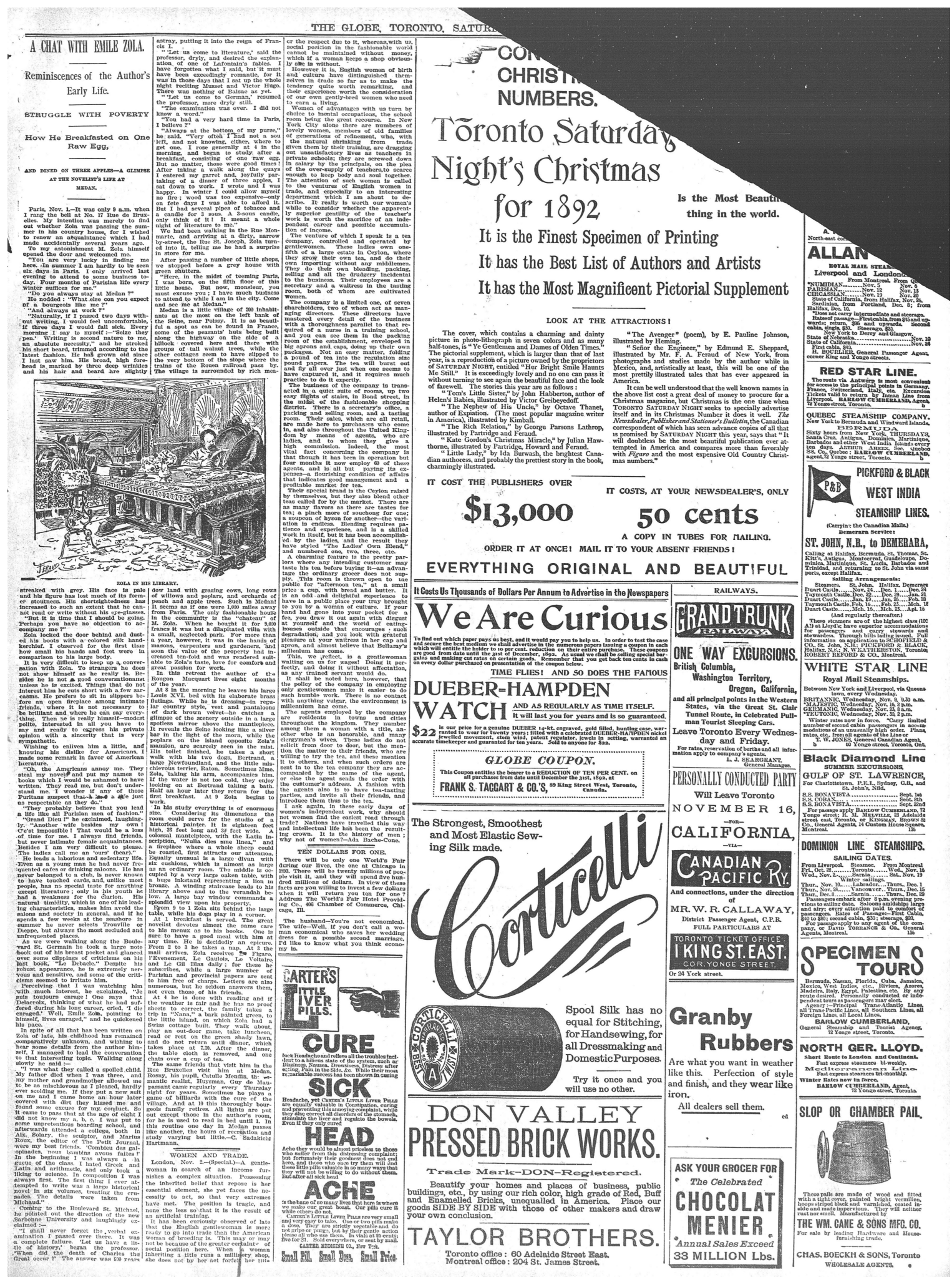

Reproduced with permission of the copyright owner. Further reproduction prohibited without permission. 


\section{Notes}

${ }^{1}$ Comme l'a remarqué Marie-Clémence Régnier, « Dans l'interview-type, la description de l'intérieur sert de seuil à l'article et conditionne la prise de parole » (75).

2 II s'agit d'une reproduction signée Feraud de la photographie de Zola dans son cabinet de travail prise par Dornac en 1890.

${ }^{3}$ C'est ce qui expliquerait les nombreuses coquilles retrouvées dans le texte dans son format original. Elizabeth S. Blake, remarque dans son étude sur les échanges entre Mallarmé et Sadakichi-Hartman, que « ni le français, ni l'anglais n'étaient la langue maternelle » de ce dernier et que l'on retrouve de nombreuses fautes dans les textes qu'il publie dans ces langues. Voir Blake p. 30.

${ }^{4}$ En fait, Zola habitait à Paris, depuis 1889, au 21 bis rue de Bruxelles.

${ }^{5}$ La relation de Zola avec Jeanne Rozerot a débuté en 1888. Alexandrine, l'épouse officielle du romancier, a découvert la liaison en 1891. Alexandrine et Émile sont restés unis par les liens du mariage jusqu'au décès de ce dernier. On peut supposer ici, si l'on croit en la véracité des propos rapportés, que Zola désirait sans doute préserver son intimité et ne pas étaler au grand public ses affaires familiales.

${ }^{6}$ Le roman était paru chez Charpentier et Fasquelle, peu de temps avant cette entrevue, le 21 juin 1892.

\section{Bibliographie}

Blake, Elizabeth S. « Un correspondant américain de Mallarmé ». Revue d'histoire littéraire de la France, 1968, no. 01, pp. 26-35.

Régnier, Marie-Clémence. « Le spectacle de l'homme de lettres au quotidien : de l'intérieur bourgeois à l'intérieur artiste (1840-1903) ». Romantisme, vol. 168, no. 2, 2015, pp.71-80.

Speirs, Dorothy E. et Dolores A. Signori. Entretiens avec Zola. Presses de l'Université d'Ottawa, 1990. 